\title{
THE MODE OF ACTION OF PHENYLINDANEDIONE
}

\author{
BY
}

\author{
W. WALKER AND R. B. HUNTER
}

From the Department of Pharmacology and Therapeutics, University of St. Andrews Medical School, Dundee, and the Therapeutics Unit, Maryfield Hospital, Dundee

(RECEIVED FOR PUBLICATION OCTOBER 6, 1953)

Since the discovery (Soulier and Gueguen, 1947) that phenylindanedione (P.I.D.) was an anticoagulant which effectively altered the one-stage prothrombin time it has been used extensively in the treatment of cases of thrombosis (Blaustein, 1950 ; Blaustein, Shnayerson, and Wallach, 1953 ; Dennis, Coon, Hodgson, and Duff, 1952 ; Toohey, 1953). Clinically it appears to produce the same effect as dicoumarol, but its action is more rapid and less prolonged (Blaustein, 1950; Jaques, Gordon, and Lepp, 1950; Bjerkelund, 1950). Sufficient experience has not yet been accumulated to compare its efficacy with that of tromexan (ethyl-biscoumacetate), though the available data suggest that both are valuable in the treatment of thrombosis, leading to a reduction in thromboembolic complications. There is no clear evidence of the precise mode of action of phenylindanedione.

If a drug causes a prolongation of the clotting time in the one-stage prothrombin test this does not necessarily mean that prothrombin itself is involved. Confusion has arisen because some workers have made this assumption on the basis of the one-stage test, and as a result it is usually stated that P.I.D. depresses prothrombin production by the liver. It is now accepted that at least three factors influence the clotting time in this test, viz., factor V, factor VII, and prothrombin itself. Although the test, which was originally designed (Quick, Stanley-Brown, and Bancroft, 1935) to measure prothrombin as such, remains a satisfactory one for routine control of anticoagulant therapy, it is not a satisfactory research or diagnostic method because it does not distinguish between deficiencies of the three factors.

Owren (1951) and Owren and Aas (1951) stated that both prothrombin and proconvertin (factor VII) were decreased by phenylindanedione. Bjerkelund (1950) found that phenylindanedione depressed prothrombin in man, but the method he used (Owren, 1949) for estimating prothrombin makes no distinction between prothrombin and factor VII, being a measure of both. The same criticism applies to the experiments of Molho (1952) in rabbits: he reported that the main effect was on prothrombin. Richards (quoted by Jaques, 1950 ) and Seegers (quoted by Jaques, 1950) both found a marked fall in prothrombin in dogs given phenylindanedione, with a slight fall in factor $\mathrm{V}$ acglobulin). Once again, however, it would appear that " prothrombin " as described by these workers includes both prothrombin and factor VII, so that either or both could be affected by the administration of phenylindanedione.

In order to determine which of the factors is principally affected by phenylindanedione the following methods were used.

\section{Preparations}

Factor V.-Normal citrated plasma was treated with $\mathrm{Al}(\mathrm{OH})_{3}$ as described by Biggs, Douglas, and Macfarlane (1953). Aluminium hydroxide $\mathrm{C} \alpha, 0.1-$ $0.4 \mathrm{ml}$., prepared by the method of Bertho and Grassman (1938), was added to $2 \mathrm{ml}$. of citrated plasma, and the mixture incubated at $37^{\circ} \mathrm{C}$. for 15 minutes. The $\mathrm{Al}(\mathrm{OH})_{3}$ was then removed by centrifuging, and the one-stage prothrombin test done on the supernatant plasma to ensure that the clotting time was longer than one minute. By this means, prothrombin and factor VII are removed by adsorption, leaving factor V. (This preparation also contains antihaemophilic globulin, and is used as a source of both factor $\mathrm{V}$ and antihaemophilic globulin in the blood thromboplastin generation test.)

Factor VII.-Normal blood was clotted in a glass tube containing three glass beads and incubated at $37^{\circ} \mathrm{C}$. for one hour to promote maximum prothrombin conversion. The serum was then used as a source of factor VII.

Thromboplastin.-This was prepared from fresh human brain by the method described by Biggs and Macfarlane (1953a), and with it normal plasma gave a one-stage clotting time (Quick's test) of 11 to 14 seconds.

Calcium.-M-40 calcium chloride solution was used. 
P.I.D. Plasma.-This term refers to plasma taken from a patient receiving phenylindanedione. Addition of P.I.D. to plasma in vitro has no effect.

Diluting Fluid.-Where tests were done with diluted plasma, normal saline was used as the diluting fluid.

Dosage of Phenylindanedione.-The dose was 100 mg. given twice on the first day, and thereafter 50-150 mg. daily in two doses, according to the response.

\section{Determinations of Clotting Defect in P.I.D. Plasma}

(1) Quick's One-stage Test.-When the one-stage test of Quick et al. (1935) gives a prolonged clotting time with a test plasma, the addition to the test plasma of a $10 \%$ concentration of the missing factor (factor V, factor VII, or prothrombin) results in a significant shortening of the clotting time towards that of normal plasma (Biggs and Macfarlane, 1935b ; Biggs and Douglas, 1953a). In our experiments, Quick's test was done on the plasmas of 38 patients under treatment with phenylindanedione, with prolongation of the "prothrombin" times (Table I). The test was then repeated using as test plasma, first, a mixture of $90 \%$ P.I.D. plasma with $10 \%$ factor V preparation; secondly, as test plasma, a mixture of $90 \%$ P.I.D. plasma with $10 \%$ factor VII preparation ; thirdly, as test plasma, a mixture of $90 \%$ P.I.D. plasma with $10 \%$ normal plasma. This last mixture contains all three factors, including prothrombin, and if deficiency in prothrombin were responsible for the prolonged clotting time, then a greater shortening of the time would be expected from the addition of normal plasma to the test plasma than from the addition of the serum preparation, which contains only factor VII.

As shown in Table I, the greatest shortening of the clotting time in all cases results from the addition of $10 \%$ factor VII preparation-often, indeed, the correction is complete, the clotting time reaching that of normal plasma. The clotting time is corrected to a less extent by the admixture of normal plasma, and not at all by the admixture of factor $V$. This suggests that P.I.D. has no action on factor $V$, and that it acts on factor VII rather than on prothrombin. 10 secs.
In the first 10 cases of the series, moreover, $10 \%$ of tromexan plasma and $10 \%$ of tromexan serum were added to the P.I.D. plasma, and the onestage test repeated. No significant reduction of

TABLE I

\begin{tabular}{|c|c|c|c|c|c|}
\hline $\begin{array}{l}\text { Case } \\
\text { No. }\end{array}$ & $\begin{array}{l}\text { Normal } \\
\text { Plasma } \\
\text { Alone }\end{array}$ & $\begin{array}{c}\text { P.I.D. } \\
\text { Plasma } \\
\text { Alone }\end{array}$ & $\mid \begin{array}{l}90 \% \% \text { P.I.D.+ } \\
10 \% \text { Factor } \\
\text { Preparation }\end{array}$ & \begin{tabular}{|c}
$90 \%$ P.I.D. + \\
10\% Factor \\
VII \\
Preparation
\end{tabular} & $\begin{array}{l}90 \% \text { P.I.D. + } \\
10 \% \text { Normal } \\
\text { Plasma }\end{array}$ \\
\hline $\begin{array}{l}1 \\
2\end{array}$ & $\begin{array}{l}11 \\
12\end{array}$ & $\begin{array}{l}20 \\
36\end{array}$ & $\begin{array}{l}20 \\
36\end{array}$ & $\begin{array}{l}11 \\
17\end{array}$ & $\begin{array}{l}14 \\
20\end{array}$ \\
\hline$\dot{0}$ & : & & : & : & : \\
\hline $\begin{array}{l}37 \\
38\end{array}$ & $\begin{array}{l}13 \\
10\end{array}$ & $\begin{array}{l}23 \\
15\end{array}$ & $\begin{array}{l}24 \\
15\end{array}$ & $\begin{array}{l}14 \\
10\end{array}$ & $\begin{array}{l}19 \\
13\end{array}$ \\
\hline $\begin{array}{l}\begin{array}{l}\text { Mean } \\
\text { values }\end{array} \\
\end{array}$ & 12 & 26 & 26 & 13 & 19 \\
\hline
\end{tabular}

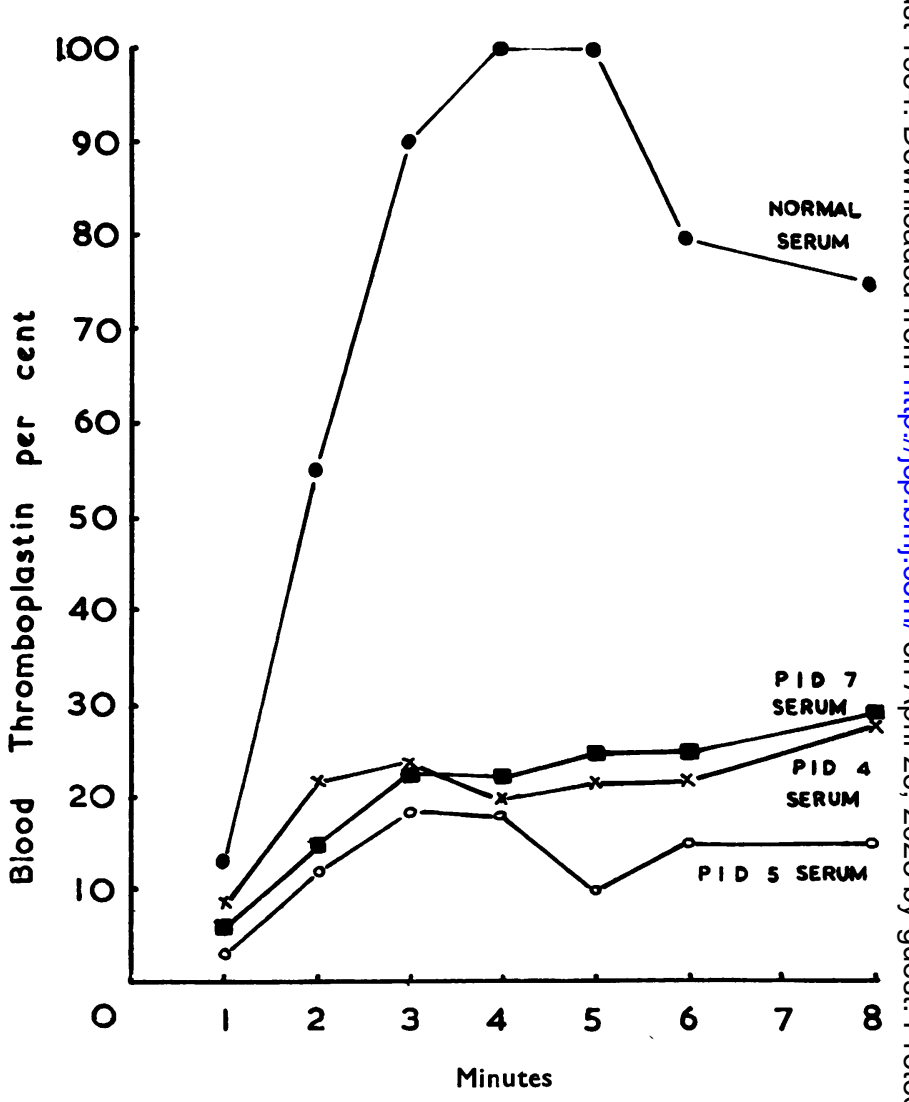

FIG. 1.-The curves show thromboplastin generated from normal Al(OH) plasma and platelets using normal serum (upper curve), and from the same mixture using three P.I.D. sera (lower curves). All of 25 P.I.D. sera treated gave similar curves. $100 \%$ thromboplastin represents clotting time in substrate vlasma of 
the clotting time resulted in any case. As plasma from tromexan-treated patients lacks factor VII (Hunter and Tudhope, 1953), this is further evidence that the defect in P.I.D. plasma is also in factor VII.

(2) Estimation of Prothrombin in P.I.D. Plasma. -In 10 cases of the series the prothrombin content of P.I.D. plasma was measured by the twostage area method (Biggs and Douglas, 1953a). The results are given in Table II, together with the

TABLE II

COMPARISON OF “ PROTHROMBIN ACTIVITY” OF P.I.D. PLASMA WITH PROTHROMBIN BY TWO METHODS

\begin{tabular}{|c|c|c|c|c|}
\hline \multirow[b]{2}{*}{$\begin{array}{l}\text { Case } \\
\text { No. }\end{array}$} & \multicolumn{3}{|c|}{ One-stage Test } & \multirow{2}{*}{$\begin{array}{c}\text { 2-stage } \\
\text { Test } \\
\text { P.I.D. } \\
\text { Plasma } \\
\text { Prothrombin } \\
\text { (\% of } \\
\text { Normal) }\end{array}$} \\
\hline & $\begin{array}{l}\text { Clotting } \\
\text { Time } \\
\text { Normal } \\
\text { Plasma } \\
\text { (Secs.) }\end{array}$ & $\begin{array}{l}\text { Clotting } \\
\text { Time } \\
\text { P.I.D. } \\
\text { Plasma } \\
\text { (Secs.) }\end{array}$ & $\mid \begin{array}{c}\text { Prothrombin } \\
\text { Activity" } \\
\text { P.I.D. } \\
\text { Plasma (\% } \\
\text { of Normal) }\end{array}$ & \\
\hline $\begin{array}{l}29 \\
30 \\
31 \\
32 \\
33 \\
34 \\
35 \\
36 \\
37 \\
38\end{array}$ & $\begin{array}{l}14 \\
14 \\
11 \\
11 \\
11 \\
11 \\
11 \\
11 \\
13 \\
10\end{array}$ & $\begin{array}{l}45 \\
29 \\
20 \\
15 \cdot 5 \\
14 \\
24 \\
17 \\
20 \\
23 \\
15\end{array}$ & $\begin{array}{l}10 \\
16 \\
25 \\
35 \\
43 \\
18 \\
30 \\
25 \\
20 \\
33\end{array}$ & $\begin{array}{l}28 \\
92 \\
47 \\
61 \\
70 \\
32 \\
69 \\
41 \\
35 \\
38\end{array}$ \\
\hline
\end{tabular}

corresponding one-stage "prothrombin" times and the percentage of "prothrombin activity" they represent on a saline dilution curve. In no case did the prothrombin, measured by the twostage area method, fall below $28 \%$ of normal, with a range of $28 \%$ to $92 \%$. According to Biggs and Douglas (1953a) reduction in prothrombin has little or no effect on the one-stage test until a level of $10 \%$ of normal is reached. If this is so, the lengthening of the one-stage "prothrombin " time when P.I.D. is administered in therapeutic doses may be attributed entirely to a reduction in factor VII.

(3) Blood Thromboplastin Generation Test.-In order to confirm that a clotting factor normally present in serum is lacking in patients treated with phenylindanedione, the blood thromboplastin generation test (Biggs et al., 1953; Biggs and Douglas, 1953b) was used. This test demonstrates the formation of potent thromboplastin from a mixture of blood clotting factors, viz., platelet suspension, antihaemophilic globulin, factor V, factor VII, Christmas factor, and calcium. Normal serum is used as a source of factor VII and Christmas factor. This test was done using normal serum and also serum from 25 of the P.I.D.treated patients, all the other factors being present in optimal amounts. In every case, thromboplastin generation with P.I.D. serum was defective (Fig. 1). The deficiency is not in Christmas factor, as lack of this factor does not prolong the clotting time in Quick's test, and is therefore probably in factor VII.

\section{Summary}

Phenylindanedione (P.I.D.) administration results in a reduction of both prothrombin and factor VII. With therapeutic doses the prothrombin deficiency is not of sufficient degree to influence coagulation and therefore the principal and important site of action of P.I.D. is factor VII. We have demonstrated that blood thromboplastin generation is impaired when P.I.D. serum is used as a source of factor VII. It is probable that the clinical results with phenylindanedione and the coumarin type anticoagulants are due to this and not to the effect on prothrombin.

We are indebted to Dr. Ann C. Donald for assistance in carrying out the prothrombin estimations, and Mr. T. Black for technical assistance. Part of the expenses of this research were defrayed from a grant by the Secretary of State for Scotland.

\section{REFERENCES}

Bertho, A., and Grassmann, W. (1938). Laboratory Methods of Biochemistry. Macmillan, London.

Biggs, R., and Douglas, A. S. (1953a). Journal of Clinical Pathology, 6,15 . (1953b). Ibid., 6, 23. - and Macfarlane, R. G. (1953). J. Physiol., Lond., 119, 89. and Macfarlane, R. G. (1953a). Human Blood Coagulation and its Disorders, p. 344. Blackwell, Oxford.

(1953b). Ibid., pp. 206-7.

Bjerkelund, C. J. (1950).' Scand. J. clin. Lab. Invest., 2, 83.

Bjerkelund, C. J. (1950). Scand. J. clin. Lab. Inve

- Shnayerson, N., and Wallach, R. (1953). Amer. J. Med., 14, 704.

Dennis, E. W., Coon, W. W., Hodgson, P. E., and Duff, I. F. (1952). J. Lab. clin. Med., 40, 792.

Hunter, R. B., and Tudhope, G. R. (1953). Lancet, 1, 821.

Jaques, L. B., Gordon, E., and Lepp, E. (1950). Canad. med. Ass. $J ., 62,465$.

Molho, D. (1952). C.R. Acad. Sci., Paris, 234, 1323.

Owren, P. A. (1949). Scand. J. clin. Lab. Med., 1, 81.

(1951). International Society of Hematology, Proc. Third International Congress, Cambridge, England, 1950, p. 475. Grune and Stratton, New York.

- and Aas, K. (1951). Scand. J. clin. Lab. Invest., 3, 201.

Quick, A. J., Stanley-Brown, M., and Bancroft, F. W. (1935). Amer. J. med. Sci., 190, 501 .

Richards, A. J. Quoted by Jaques, L. B. (1950). Blood Clotting and Allied Problems. Third Conference, p. 24. Josiah Macy, Jr., Foundation, New York.

Seegers, W. H. Q loted by Jaques (1950). Ibid., p. 24.

Soulier, J. P., and Gueguen, J. (1947). C.R. Soc. Biol., Paris, 141, 1007.

Toohey, M. (1953). Brit. med. J., 1, 650. 